\title{
An Analysis of the
}

\section{Competitiveness and Market Expansion of Thailand's Rubber Smoked Sheet Exports - A Technical Note}

\author{
Thanet Wattanakul ${ }^{1}$, Sakkrin Nonthapot ${ }^{2}$ and Tanawat Watchalaanun ${ }^{3}$
}

\begin{abstract}
This study aims to investigate the effect of market share and total RMS imports by Thailand's RMS partner importers by employing simultaneous equations with panel data. The data consist of 10 Thailand rubber smoked sheet (RMS) partner countries between 2008 and 2017 and are estimated by using the three stage least square technique. It was found that market share has more effect on the RMS partner imports from Thailand than the partner's market expansion while the exchange rate had a strong negative effect on market share in the partner country. As a consequence, policymakers should prioritize the formulation of suitable and effective international fiscal policy and its implementation to better allocate the benefits from trade. $^{2}$
\end{abstract}

JEL classification: O19, F62.

Keywords: Rubber Smoked Sheet, International Trade, Competitiveness, Market Expansion, Simultaneous Equation

\footnotetext{
${ }^{1}$ Indo-China International Trade and Economic Research Sector, Faculty of Integrated Social Sciences, Khon Khen University, Nong Khai Campus, Thailand.

E-mail: thanet@kku.ac.th

${ }^{2}$ Indo-China International Trade and Economic Research Sector, Faculty of Integrated Social Sciences,

Khon Khen University, Nong Khai Campus, Thailand.

E-mail: sakkno@kku.ac.th

${ }^{3}$ Indo-China International Trade and Economic Research Sector, Faculty of Integrated Social Sciences,

Khon Khen University, Nong Khai Campus, Thailand.

E-mail: gng3379@gmail.com

Acknowledgements:

This research study would not have been possible without the kind support and assistance of Khon Kaen University, Nong Khai Campus and the Indo-China International Trade and Economic Research Sector funding.
} 


\section{Introduction}

Latex is a necessary material and component in the manufacture of many products. However, raw latex has limitations in maintaining a high level of quality and is difficult to transfer. Rubber smoked sheet (RMS) is a product which is transformed from latex and its use can solve the problem stated above. The product is also widely used in the production processes of many industries. However, RMS exporters are faced with substitute goods such as synthetic rubber, which has been developed in recent years and affects the rubber market.

Since 2001, the import value of RMS in the world market has fluctuated. Although the longterm trend between 2001 and 2017 was increasing, there were short term fluctuations in terms of import value throughout the period (figure 1).

Figure 1 Total World and Top Market RMS Imports from 2001 to 2017

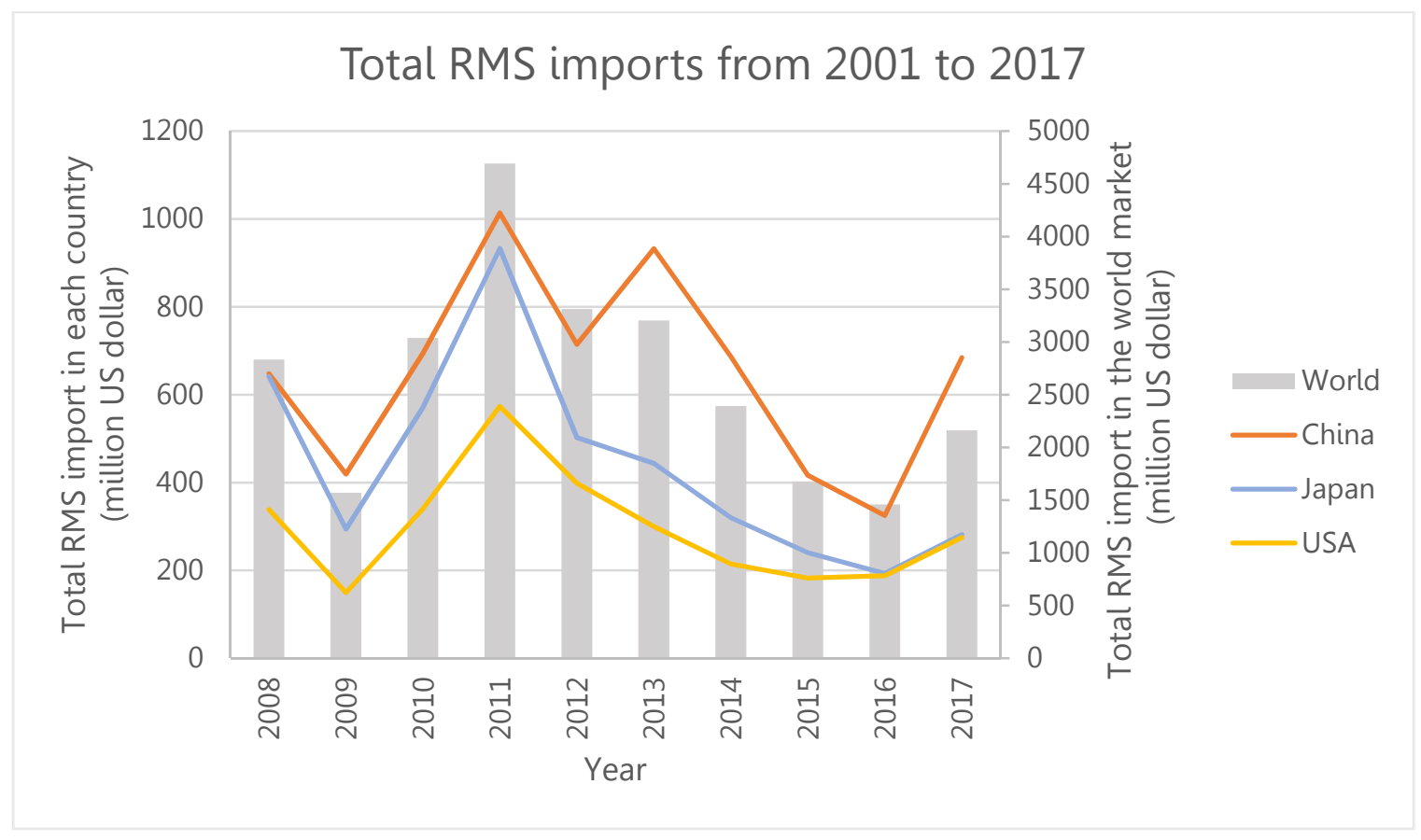

Source: Trade map (2018)

On the supply side, the top exporters in the RMS market are mostly ASEAN countries. Thailand is the biggest exporter over the period since 2001 while the second, third and fourth largest exporters are Indonesia, Singapore, Myanmar and Viet Nam. Thailand had more than a $70 \%$ market share of the world market over the 17 years since 2001 as a result of superior quality. However, the weakness of Thailand is the higher cost of production and development than in other countries. Furthermore, the majority of Thai RMS supplier's revenue depends on the export sector because there are only a few related downstream industries (Bawonkullawat, 2011). Thus, the situation in the world RMS market significantly affects producers in Thailand's RMS supply chain, especially farmers.

Since 2001, Thailand RMS exports to the world market were valued at 28.22 billion US dollars or 72.79 percent of the world RMS market. Thailand's RMS export value has moved 
in line with world trends and market share. From 2001 to 2003, Thailand's RMS exports increased as the world RMS export market grew but between 2005 and 2009 it decreased in the world RMS market and Thailand's RMS export value was affected by the lower market share.

Figure 2 Total World and Thailand RMS Exports between 2001 and 2017

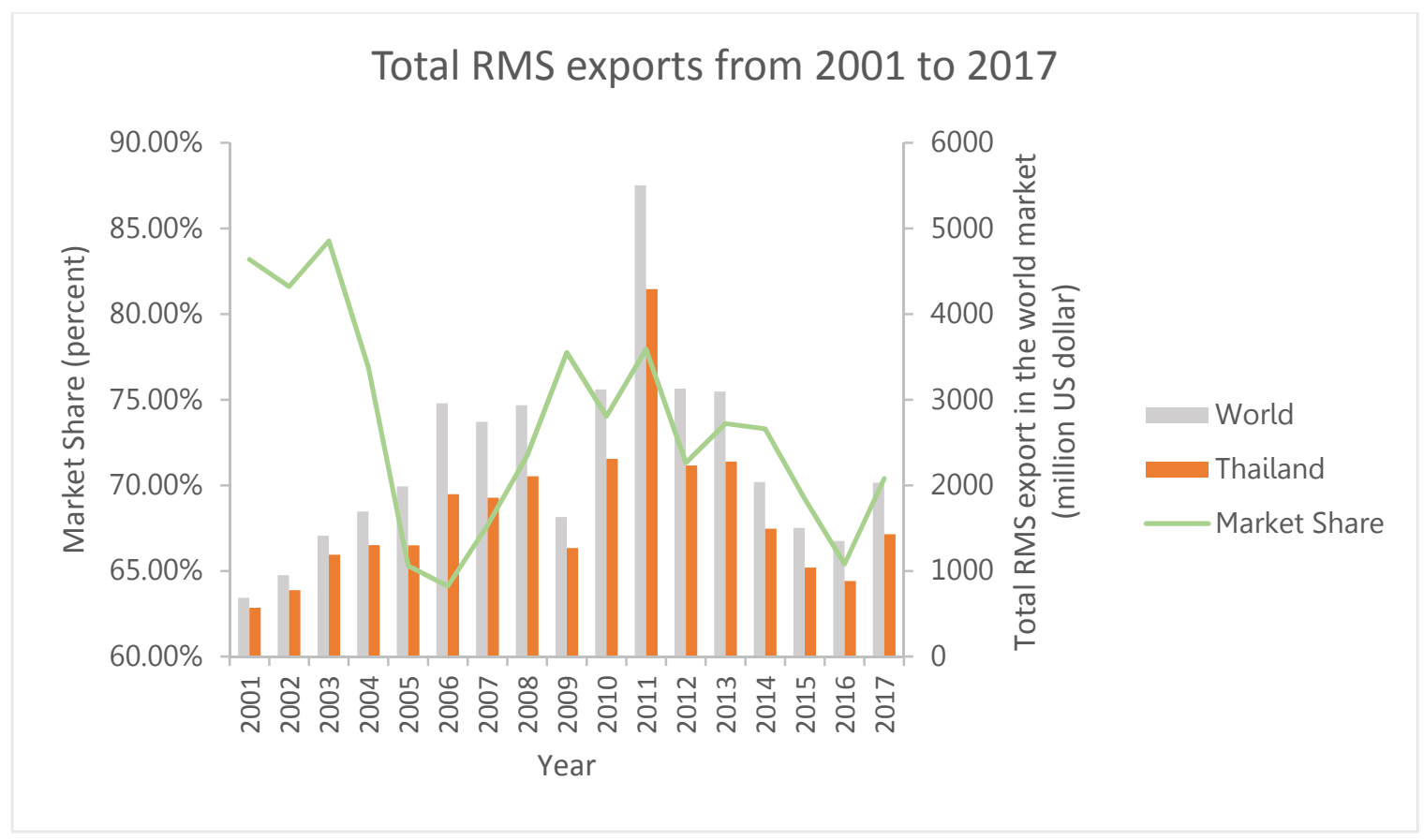

Source: Trade map (2018)

Moreover, there was a decreasing trend in the RCA index of RMS export value as well as an effect in the Constant Market Share model (CMS model) in this market between 1997 and 2016 (Wattanakul, 2018). The CMS model presents the changes in Thailand RMS exports between 1997 and 2016 which greatly increased as a result of the rapid increase in world growth. On the other hand, the competitiveness effect and the interaction effect were the cause of the decrease while the market distribution effect caused both effects during that period. This situation revealed that the competitiveness of Thai exports in this market continually decreased.

In 2017, the Top 10 RMS importer countries from Thailand were China, Japan, USA, France, India, Brazil, Spain, Taiwan, Turkey and Italy. Only 3 countries. Japan, France and Brazil imported more than 90 percent of their RMS from Thailand while China, USA, Spain Turkey and Italy imported about 60 to 80 percent of their RMS from Thailand. Moreover, India and Taiwan imported less than 50 percent of their RMS from Thailand (Table 1). China and the USA were the first and the third most important partners and RMS importers in the world market. However, there is intense competition to export to these countries. There is an opportunity to export to these countries if Thailand can enhance the competitiveness of the RMS industry. 
Table 1 The RMS Import Value of Thailand's Partner Countries

\begin{tabular}{|l|c|c|c|}
\hline \multirow{2}{*}{\multicolumn{2}{c|}{ Country }} & \multicolumn{2}{c|}{ RMS Imports } \\
\cline { 2 - 4 } & $\begin{array}{c}\text { Total RMS } \\
\text { import value }\end{array}$ & $\begin{array}{c}\text { RMS import value } \\
\text { from Thailand }\end{array}$ & Market Share \\
\hline China & 331,081 & 243,828 & $73.65 \%$ \\
\hline Japan & 131,577 & 125,203 & $95.16 \%$ \\
\hline United States of America & 117,740 & 82,358 & $69.95 \%$ \\
\hline France & 29,197 & 26,506 & $90.78 \%$ \\
\hline India & 55,924 & 22,140 & $39.59 \%$ \\
\hline Brazil & 26,109 & 24,097 & $92.29 \%$ \\
\hline Spain & 18,490 & 12,668 & $68.51 \%$ \\
\hline Taiwan (Chinese) & 39,640 & 18,235 & $46.00 \%$ \\
\hline Turkey & 30,583 & 18,829 & $61.57 \%$ \\
\hline Italy & 23,694 & 17,340 & $73.18 \%$ \\
\hline
\end{tabular}

Source: Trade map (2018)

In 1970, the relationship between competitiveness and export value was presented by Leamer and Stem in the Constant Market Share Model (CMS model). This has since been further developed by many economists. This model assumes that competitiveness is related to market share. The total export value for a country is determined by the total export value in the world market and the market share of the country in the world market. The change in the world market, which affects the change in the total exports of a country, is a world growth effect while the change in the market share of the country which affects the change in the total export of the country is a pure competitiveness effect. The change in total exports is explained by another effect. The joint effect between the world growth effect and the competitiveness effect is called the interaction effect. Although the concept can explain the phenomenon of Thailand's RMS exports, each effect was also influenced by many other related factors.

According to the basic CMS concept presented above, the changes in export value was affected by the changes in total exports to the market and the changes in market share while both causes were determined by other factors. In regard to imports, Khiyavi, Moghaddasi and Yazdani, (2013) found that trade in agricultural products was influenced by the growth in the market size of the exporting and importing countries. Moreover, income per capita had a positive influence on trade flow value in developing countries. Öztürk (2012) revealed the effect of macroeconomic factors on imports in Turkey in that there is a positive effect from exports, Gross Domestic Product and real effective exchange rate on imports. These studies indicate a linkage between macroeconomic factors on partner imports and the effect of market size on imports.

The competitiveness effect on market share was also found to be influenced by many factors. Konstantin, Benkovskin and Wörz (2018) studied the impact of price and non-price on market share, which applies the demand concept in the analysis. The study revealed that there is a stronger effect of non-price factors, such as taste and quality, on market share than 
relative price. Aghili, Salmani and Hosseini (2017) found a significantly negative direction from the ratio of the Export Price Index of Iran to the Consumer Price Index in Singapore, the ratio of Singapore's population to Iran's labor force, the similarity between Iran and Singapore on the Iranian hand-woven carpet market share in Singapore, the positive effect of the real exchange rate between the Singapore and Iran currency, the ratio of Singapore's GDP per capita to Iran's GDP per capita and the protection rate of Iranian hand-made carpet exports on market share.

According to the passage above, the import of any goods from any country was found to be affected by the market expansion/reduction of the goods or total import of the goods of the importer country and the competitiveness of the export country in the importer country market. Both factors were found to be affected by related macroeconomics factors. All factors which are determined by other factors are endogenous variables while the independent factors are exogenous variables. The influence of the exogenous variables on the endogenous variables probably distorts the empirical results in a single equation which is estimated by the ordinary least square estimator, but simultaneous equations may be more suitable for a system equation, and three stage least square estimator method is probably appropriate and efficient because of the properties of the two stage least square and general least square process in the method.

\section{Methodology}

This study was conducted using simultaneous equations with panel data for 10 years from 2008 to 2017 from the top 10 partner countries: China, Japan, USA, France, India, Brazil, Spain, Taiwan (China), Turkey and Italy. These relationships are estimated by using the three stage least square method of simultaneous equations as follows:

$$
\begin{aligned}
T h_{i t} & =\beta_{0}+\beta_{1} S_{i t}+\beta_{2} W_{i t}+u_{i t} \\
S_{i t} & =\alpha_{1}+\alpha_{2} P_{i t}+\alpha_{3} E x c_{i t}+v_{i t} \\
W_{i t} & =\gamma_{0}+\gamma_{1} G D P_{i t}+\gamma_{3} M o_{t}+w_{i t}
\end{aligned}
$$

When $T h_{i t}$ is the i country RMS import quantity from Thailand in period t (Tons), $S_{i t}$ is market share or the competitiveness effect of $\mathrm{i}$ country in period $\mathrm{t}$ (percent), $W_{i t}$ is total RMS import quantity of partner country or the market distribution of i country in period $t$ (Tons), $P_{i t}$ is the average price of $\mathrm{i}$ country in period $\mathrm{t}$ (US dollar per Tons), $E x c_{i t}$ is the indirect code exchange rate of $i$ country currency per Thailand currency (Baht or local currency) in period $t$ (importer currency per Baht), GDP $i t$ is i country real GDP in constant price at 2010 on period $\mathrm{t}$ (US dollar in millions) $M o_{i t}$ is the pneumatic tires of rubber quantity export of Thailand's RMS partner countries (Tons), while are the parameters and $\beta_{0}, \alpha_{0}$ and $\gamma_{0}$ are errors term in each equation. $W_{i t}$. $t h_{i t}, w_{i t}, P_{i t}$ were collected from Trade Map while $G D P_{i t}$ was collected from the World Bank while Excit was collected from OFX and $S_{i t}$ was calculated by $S_{i t}=100 \times \frac{T h_{i t}}{W_{i t}}$. 
Eq (1) presents the relationship between market expansion and competitiveness on RMS partner imports from Thailand when market expansion is represented by the term $W_{i t}$ and competitiveness is represented by the term $S_{i t}$. Eq (2) presents the factors which affect the market share, such as price and exchange rate while in eq (3) represents the factors which affect the total RMS import of the partners such as GDP and pneumatic tire exports of partner countries.

This simultaneous equation system confirmed the identified property by rank and order condition for identification testing. Coefficients which were estimated by the three state least square method was efficient and was the best linear unbiased estimator (BLUE).

\section{Results}

The empirical result in eq (1) shows the positive significant effect of market share (competitiveness) and total RMS import quantity of the partner (market size) on RMS quantity imports from Thailand by partners (Table 2). The relationship between the total RMS quantity imports of partner countries (market expansion) and RMS quantity imports from Thailand represents the role of Thailand RMS which is the important resource of RMS in the partner market. For an increase in total RMS quantity imports of partner countries of 1 ton, there is 0.7749 tons which is imported from Thailand. Furthermore, the relationship between RMS market share (Competitiveness) and RMS quantity imports from Thailand in the market shows the importance of competitive strategy in the market. If the RMS market share of Thailand in the partner country increases by about 1 percent, there is an increase of 850.575 tons of RMS imports by the partners of Thailand. As a result, it can be affirmed that Thailand is the biggest exporter of this product to the market.

Table 2 Factors that influence Thailand's RMS exports

\begin{tabular}{|c|c|c|}
\hline $\begin{array}{l}\text { Independent } \\
\text { variable }\end{array}$ & Coefficient & T-statistics \\
\hline Intercept & -63687.06 & $-13.4813 * * *$ \\
\hline $\mathrm{S}$ & 850.575 & $13.8561 * * *$ \\
\hline W & 0.7749 & $62.0648 * * *$ \\
\hline R square & Adjusted R square & 0.9813 \\
\hline D.W. statistic & 0.4215 & \\
\hline
\end{tabular}

Note: $* * *$ is significant at 99 percent.

Considering Thailand's RMS market share of the partner market in eq (2), there are two essential factors that determine market share, which are exchange rate and price. There is a strong negative effect of the exchange rate on total RMS partner imports from Thailand while the RMS average price is weak. When the partner currency appreciates compared to the baht or the baht depreciates compared to the partner currency, there is a significant increase in the Thailand RMS market share in the RMS partner market. However, RMS average price has a positive direction effect on market share as a result of the weaker effect than the previous factor. Thus, policymakers can influence the market share or improve the competitiveness effect by using international fiscal policy while the weakness effect of price on the RMS 
imports of the partner has more influence than quality. This empirical result is consistent with Benkovskin and Wörz (2018) who investigated the mineral and non-mineral products of different countries.

Table 3 Factors that influence Thailand's RMS market share

\begin{tabular}{|c|c|c|}
\hline $\begin{array}{l}\text { Independent } \\
\text { variable }\end{array}$ & Coefficient & T-statistics \\
\hline Intercept & 79.2955 & $33.1060 * * *$ \\
\hline Ex & -27.8885 & $-18.7731 * * *$ \\
\hline $\mathrm{P}$ & 0.0016 & $2.0009 * *$ \\
\hline R square & Adjusted R square & 0.6982 \\
\hline D.W. statistic & 0.5454 & \\
\hline
\end{tabular}

Note: *** is significant at 99 percent and ** is significant at 95 percent.

There is a significant positive influence of GDP and the quantity of pneumatic tires of rubber export quality on the total RMS imports of partner countries. The increase in the quality of pneumatic tires of rubber quantity export affects the quantity of RMS partner imports because RMS is a necessary factor in the rubber manufacturing process of pneumatic tires. The GDP of the partner country affects the total RMS imports of the partner country as can be seen in in the study of Thapa and Adhikari (2014) in regard to the effect of total imports and exports

Table 4 Factors that influence partner RMS

\begin{tabular}{|c|c|c|}
\hline $\begin{array}{l}\text { Independent } \\
\text { variable }\end{array}$ & Coefficient & T-statistics \\
\hline Intercept & 21522.71 & $4.1779 * * *$ \\
\hline GDP & 0.0042 & $5.3722 * * *$ \\
\hline Mo & 0.0412 & $14.1471 * * *$ \\
\hline R square & Adjusted R square & 0.7397 \\
\hline D.W. statistic & 0.5131 & \\
\hline
\end{tabular}

Note: $* * *$ is significant at 99 percent.

\section{Conclusion}

Based on the empirical results, the positive effects of market share (Competitiveness) and total RMS import of Thailand partner countries (Market size) on the RMS import from Thailand are revealed. However, the market share has a greater effect on RMS imports from Thailand by partner countries than the RMS market expansion in the partner country.

Moreover, this study reveals the importance of the exchange rate on the market share in this market with a strong negative effect of exchange rate on market share in the partner country. Baht depreciation will create an advantage for Thailand in this industry in partner countries. However, the positive effect of average price, which has little effect on the change in market 
share, is unusual. International fiscal policy could be employed as it is a crucial economic policy to enhance competitiveness.

In addition, there is a positive effect of GDP and the quantity of pneumatic tires of export quality rubber on the total RMS imports of partner countries. This result shows the importance of the economic situation of Thailand partner countries on this trade. The situation of partner economies should be an advantage for Thailand RMS suppliers for production planning and in preventing oversupply, which may lead to massive price decreases.

This study indicates the importance of defending market share in each market and the effect of international fiscal policy on international trade. Policymakers should prioritize the use of international fiscal policy to regulate this trade especially by controlling the exchange rate.

\section{References}

Benkovskin K. and Wörz, J. (2018). What drives the market share changes? Price versus non-price factor, Structural Change and Economic Dynamics 45(2018); 9-29. https://doi.org/10.1016/j.strueco.2017.12.001

Khiyavi K., Moghaddasi. R and Yazdani. S., (2013). Investigation of Factors Affecting the International Trade of Agricultural Products in Developing Countries, Life Science Journal 2013; 10(3s)

Leamer E.F., Stern R.M. (1970) Quantitative International Economics, Aldine Transaction Editor, Chicago

Lotfali, A., Salmani, U. and M. A. Hosseini. (2017). Factors Affecting Market Share of Iranian Hand-woven Carpet in Singapore, International Journal of Economics and Financial Issues, 2017, 7(1), 500-505.

Öztürk, M. (2012). Macroeconomic Factors Affecting the Import in Turkey, Journal of QafQaz University.

Trade map. (2018). List of exporters for the selected product (Product: 400121 Smoked sheets of natural rubber). Retrieved 17 October 2018 from https://www.trademap.org/Country_SelProduct_TS.aspx?nvpm $=1 \% 7 \mathrm{c} \% 7 \mathrm{c} \% 7 \mathrm{c} \% 7 \mathrm{c} \%$ $7 \mathrm{c} 400121 \% 7 \mathrm{c} \% 7 \mathrm{c} \% 7 \mathrm{c} 6 \% 7 \mathrm{c} 1 \% 7 \mathrm{c} 1 \% 7 \mathrm{c} 2 \% 7 \mathrm{c} 2 \% 7 \mathrm{c} 1 \% 7 \mathrm{c} 2 \% 7 \mathrm{c} 1 \% 7 \mathrm{c} 1$.

Trade map. (2018). List of Importers for the selected product (Product: 400121 Smoked sheets of natural rubber). Retrieved 17 October 2018 from https://www.trademap.org/Country_SelProduct_TS.aspx?nvpm $=1 \% 7 \mathrm{c} \% 7 \mathrm{c} \% 7 \mathrm{c} \% 7 \mathrm{c} \%$ $7 \mathrm{c} 400121 \% 7 \mathrm{c} \% 7 \mathrm{c} \% 7 \mathrm{c} 6 \% 7 \mathrm{c} 1 \% 7 \mathrm{c} 1 \% 7 \mathrm{c} 1 \% 7 \mathrm{c} 2 \% 7 \mathrm{c} 1 \% 7 \mathrm{c} 2 \% 7 \mathrm{c} 1 \% 7 \mathrm{c} 1$

Walaiporn, B. (2011). The Competitiveness and Potential of Natural Rubber Industry in Thailand. Master of Economics, Thammasat University.

Wattanakul, T. (2018). The Influencing Factors of Thailand Rubber Sheet Smoke Export Value (Research Report). Indo-China International Trade and Economic Research Sector Khon Kaen University Nong Khai Campus. 